\title{
SELIGMAN CRYSTAL PRESENTATION TO GERALD SELIGMAN
}

THE institution of the Seligman Crystal and the first award to Gerald Seligman were announced in the fournal of Glaciology, Vol. 4, No. 35, p. 509. The presentation was made at the Glaciological Society's Annual General Meeting in London on 2 May rg63 and the proceedings were fully reported in the Society's news bulletin, Ice, No. 12, p. 15.

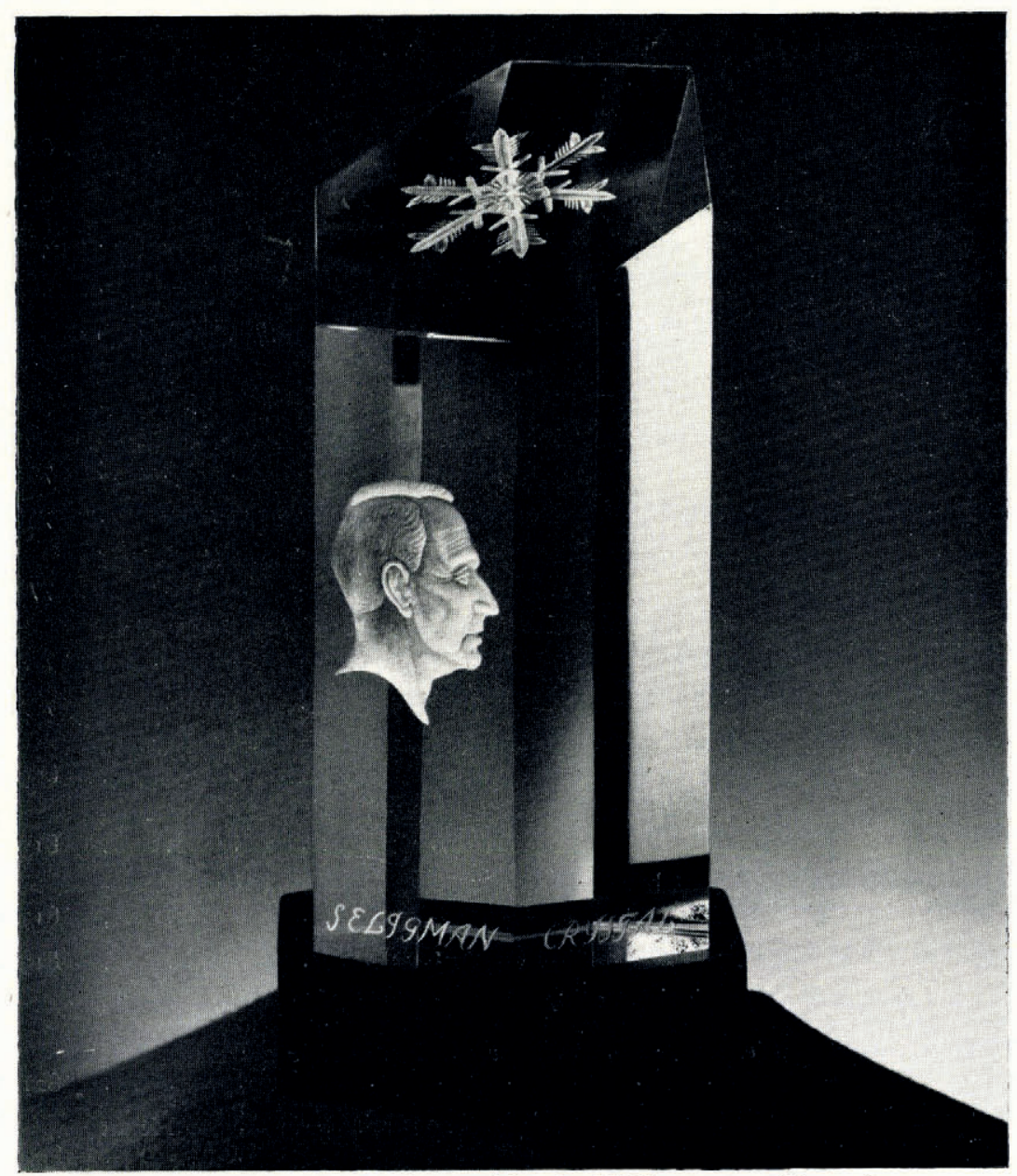

The first Seligman Crystal, awarded to Gerald Seligman on 2 May ${ }_{196} 63$

The first Seligman Crystal, shown above, is a hexagonal prism of Swedish crystal glass mounted on a wooden base and inscribed: Seligman Crystal-Glaciological SocietyG. Seligman-ig63. A snow crystal design is etched on the top sloping face and a profile of $\mathrm{Mr}$. Seligman is etched on the front face.

In making the presentation, Sir Vivian Fuchs, the Chairman of Council, referred to Mr. Seligman as the "founder and father of the Society" and expressed the Society's appreciation of all that he had done in fostering the interests of the Society and its journal. 


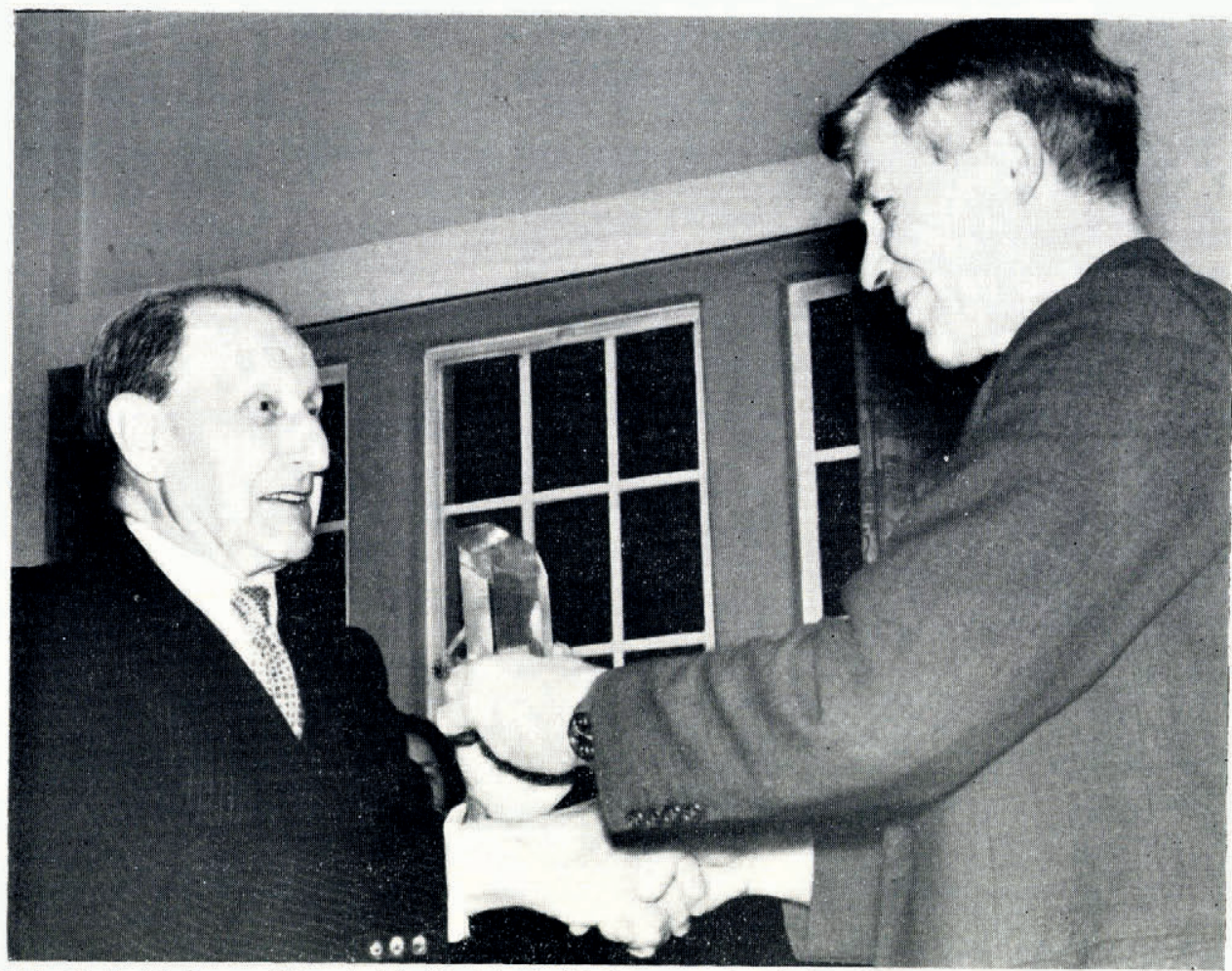

Sir Vivian Fuchs, Chairman of Council of the Glaciological Society, presenting the first Seligman Crystal to Gerald Seligman (left)

In his reply, Mr. Seligman said that it was difficult to return adequate thanks for the beautiful award, and that he felt deeply moved by the generous recognition of his services to the Society and to the science of glaciology, services which could never have been accomplished without the co-operation, active help and encouragement from friends in the United Kingdom and abroad.

Members of the Glaciological Society who attended an informal dinner later the same evening were able to examine the Crystal and drink a toast to Mr. Seligman.

Hilda Richardson

Secretary,

The Glaciological Society

\section{AWARD OF HONORARY DEGREE TO GERALD SELIGMAN BY UNIVERSITÄT INNSBRUGK}

The Leopold-Franzens-Universität Innsbruck, Austria, awarded the honorary degree of Doktor der Philosophie to Gerald Seligman, Founder of the Glaciological Society, at its Akademischen Festakt on 29 June 1963.

The citation for the degree referred to Mr. Seligman's services to science and to glaciology in particular. The presentation oration was given by the Promotor, Univ.-Prof. Dr. Herfried Hoinkes.

A fuller account of the award will be published in No. I 3 of the Society's news bulletin, Ice. 